\title{
SURVEY KEPUASAN ANGGOTA GAPOKTAN TERHADAP PERAN PENGURUS KELOMPOK TANI DI GAMPONG KULAM ARA KECAMATAN MUTIARA TIMUR KABUPATEN PIDIE
}

\author{
Julia1, Andria Syah Putra2, Nurfadhilah3 \\ Program Studi Agribisnis Fakultas Pertanian \\ Universitas Jabal Ghafur \\ e-mail agribisnisunigha@gmail.com
}

\begin{abstract}
ABSTRAK
Penelitian ini bertujuan untuk mengetahui mengetahui survey kepuasan anggota gapoktan terhadap peran pengurus kelompok tani di Gampong Kulam Ara Kecamatan Mutiara Timur. Penelitian dimulai dari 25 Juli sampai 15 Agustus 2017. Penelitian menggunakan metode deskriptif dengan populasi adalah seluruh pengurus kelompok tani di Gampong Kulam Ara Kecamatan Mutiara Timur Kabupaten Pidie sebanyak 75 orang. Penentuan sampel sebanyak 37 orang dilakukan secara ramdom sampling (pengambilan sampel secara acak). Dalam hal ini diambil sampel sebanyak 37 orang untuk keperluan penelitian. Data yang diperoleh terdiri dari data primer dan data sekunder, baik data kualitatif maupun kuantitatif. Analisis yang digunakan dalam penelitian ini adalah sebagai berikut: $\mathrm{P}=\mathrm{F} / \mathrm{NX} 100 \%$. Hasil penelitian ini menunjukkan bahwa survey kepuasan anggota gapoktan terhadap peran pengurus kelompok tani di Gampong Kulam Ara Kecamatan Mutiara Timur Kabupaten Pidie termasuk dalam kategori baik karena dapat meningkatkan perkembangan kelompok tani ditinjau dari kreatifitas, produksi dan pendapatan petani melalui musyawarah kelompok tani dan peran pengurus dalam pelaksanaan musyawarah kelompok tani berupa tentang partisipasi mengikuti kegiatan, partisipasi pada pertemuan dan kegiatan kelompok tani, partisipasi pada program penyuluhan pertanian dan tingkat kemampuan kinerja kelompok di Gampong Kulam Ara Kecamatan Mutiara Timur Kabupaten Pidie.
\end{abstract}

Kata Kunci : Gapoktan, Peran Pengurus, Kelompok Tani

\begin{abstract}
This study aims to find out the survey of gapoktan members' satisfaction survey on the role of farmer group members in Gampong Kulam Ara Kecamatan Mutiara Timur. The research started from July 25 until August 15, 2017. The research used descriptive method with population is the whole group of farmer group in Gampong Kulam Ara Sub Mutiara Timur Regency Pidie counted 75 people. Determination of sample of 37 people done by ramdom sampling (random sampling). In this case taken a sample of 37 people for research purposes. The data obtained consist of primary data and secondary data, both qualitative and quantitative data. The analysis used in this research is as follows: $\mathrm{P}=\mathrm{F} / \mathrm{NX} 100 \%$. The results of this study indicate that the survey of gapoktan members' satisfaction on the role of farmer group members in Gampong Kulam Ara Sub-district of Mutiara Timur Pidie District is included in the good category because it can improve the development of farmer groups in terms of creativity, production and income of farmers through farmer group meetings and the role of executives in the implementation deliberation of farmer groups in the form of participation participation, participation in farmer group meetings and activities, participation in agricultural extension program and group performance capability level in Gampong Kulam Ara Kecamatan Mutiara Timur Kabupaten Pidie.
\end{abstract}

Keywords: Gapoktan, Board Role, Farmer Group

\section{PENDAHULUAN}

Sampai saat ini kelompok tani masih digunakan sebagai pendekatan utama dalam kegiatan penyuluhan, Pendekatan kelompok dipandang lebih efesien dan dapat menjadi media untuk terjadinya proses belajar dan berinteraksi dari para petani, sehingga diharapkan terjadi perubahan perilaku petani ke arah yang lebih baik atau berkualitas. Dengan demikian kelompok tani memiliki kedudukan strategis dalam mewujudkan petani yang berkualitas. Petani yang berkualitas antara lain dicirikan dengan adanya kemandirian dan ketangguhan dalam berusaha tani. Untuk 
mencapai petani yang berkualitas tersebut, maka menjadi suatu keharusan bahwa kelompok tani yang ada harus memiliki gerak atau kekuatan yang dapat menentukan dan mempengaruhi perilaku kelompok dan anggota - anggotanya dalam mencapai tujuan-tujuan kelompok. Dengan kata lain kelompok tersebut harus aktif melibatkan para anggotanya.

Salah satu faktor penting untuk terwujudnya kelompok tani yang efektif adalah berjalannya kepemimpinan dari pengurus kelompok yang berperan dalam mengurusi kerja kelompok. Pengurus kelompok dapat dipandang sebagai agen primer untuk tercapainya dinamika kelompok, karena peran strategisnya dalam mempengaruhi atau menggerakan anggotaanggota kelompoknya dalam mencapai tujuan kelompok. Agar kelompok tani dapat berkembang dengan wajar, maka diarahkan agar perkembangan kelompok dapat berlangsung secara dinamis dan diarahkan agar kelompok tani jugamempersiapkan kader-kader pengurus kelompok yang akan menjadi penerus dari generasi pengurus yang sekarang demi kesinambungan eksistensi kelompok tani di masa yang akan datang (Suhardiyano, 2002).

Kelompok tani sebagai wadah anggota kelompok untuk berkembang, berinteraksi dengan para anggotanya dan mengambil keputusan dalam proses musyawarah merupakan suatu yang paling nyata dijumpai di masyarakat sosial. Kelompok tani sebagai wahana kerjasama hendaknya memiliki kemampuan merencanakan dan melaksanakan musyawarah agar tercapai kesepakatan yang bermanfaat bagi anggota. Dengan demikian perlu adanya evaluasi anggota kelompok tani terhadap tugas pengurus dalam perannya merencanakan pertemuan kelompok atau mengelola musyawarah kelompok agar berjalan dengan aktif danterpadu. Sebagaimana dikatakan Mardikanto (2003) evaluasi sebagai suatukegiatan, sebenarnya merupakan proses untuk mengetahui atau memahami dan memberikan penilaian terhadap suatu keaadaan tertentu, melalui kegiatan pengumpulan data atau fakta dengan ukuran serta cara pengukuran tertentu yang telah diterapkan. Di samping ketertarikan untuk mengevaluasi bagaimana petani anggota kelompok tani menilai peran pengurus dalam mengelola pertemuan kelompok, terdapat ketertarikan untuk membandingkan jawaban-jawaban dari anggota kelompok tani di dua daerah atau kecamatan yang memiliki populasi yang berbeda dalam jumlah kelompok tani.
Sejumlah kelompok tani yang tersebar di berbagai kecamatan di Kabupaten Pidie dikelompokkan dengan cara-cara tersendiri yaitu masing-masing berdasarkan laju berdiri, jumlah anggota, daerah jangkauan dan lainnya. Apakah perbedaan jumlah populasi kelompok tani di suatu daerah dengan daerah yang lain mempunyai evaluasi yang berbeda. Adanya daerah dengan banyak kelompok tani (KTB) berbeda dengan daerah Kelompok Tani Sedikit (KTS) adalah satu kerangka pikiran yang penulis ingin teliti lebih dalam. Evaluasi ini terbatas terhadap penilaian anggota terhadap pelaksanan banyak tugas pengurus kelompok tani yang mencakup POAC (Planning, Organizing, Actuating dan Controling) yang dapat dinilai oleh anggota kelompok tani adalah pelaksanaan musyawarah kelompok tani.

Berdasarkan uraian di atas, sehingga penulis tertarik untuk mengadakan penelitian dengan judul: "Survey Kepuasan Anggota Gapoktan Terhadap Peran Pengurus dalam Pelaksanaan Musyarawah Kelompok Tani di Gampong Kulam Ara Kecamatan Mutiara Timur Kabupaten Pidie".

\section{METODEOLOGI}

\section{Lokasi, Objek dan Waktu Penelitian}

Penelitian ini dilakukan di Gampong Kulam Ara Kecamatan Mutiara Timur Kabupaten Pidie dengan pertimbangan bahwa Gampong Kulam Ara merupakan salah satu Gampong di Kecamatan Mutiara Timur Kabupaten Pidie yang banyak terbentuk anggota kelompok tani. Untuk keperluan penelitian ini dipilih 1 Gampong dari seluruh Gampong yang ada, dengan kriteria bahwa Gampong tersebut termasuk Gampong yang berkelompok tani aktif.

Objek penelitian ini hanya terbatas pada kegaitan kelompok tani. Ruang lingkup penelitian ini adalah evaluasi kegiatan kelompok tani terhadap peran pengurus dalam pelaksanaan musyawarah kelompok tani di Gampong Kulam Ara Kecamatan Mutiara Timur Kabupaten Pidie. Pelaksanaan penelitian di rencanakan di mulai dari bulan April sampai dengan bulan Mei 2017.

\section{Populasi dan Metode Penarikan Sampel Populasi}

Populasi adalah himpunan individu atau objek yang banyaknya terbatas atau tidak terbatas. Sesuai dengan permasalahan yang akan diteliti, populasi dari penelitian ini dibagi menjadi dua yaitu populasi penduduk. Menurut 
Rafi'i (2006), “populasi adalah sejumlah variabel penelitian yang menyangkut permasalahan yang sedang diteliti atau dengan kata lain populasi identik dengan sampel".

Populasi dalam penelitian ini terdiri dari populasi wilayah dan penduduk. Populasi wilayah merupakan wilayah yang terdapat di daerah penelitian yaitu wilayah Gampong Kulam Ara Kecamatan Mutiara Timur Kabupaten Pidie yang terdapat kelompok tani. Populasi penduduk adalah semua petani yang menjadi anggota kelompok tani di Gampong Kulam Ara Kecamatan Mutiara Timur Kabupaten Pidie. Jumlah anggota kelompok tani yang ada di Gampong Kulam Ara sebanyak 75 orang.

\section{Sampel}

Sampel adalah sebagai dari objek atau individu-individu yang mewakili suatu populasi”. Sedangkan menurut suma'atmadja (2008) mempunyai sampel tidak jauh berbeda, dimana "sampel merupakan bagian dari populasi yang mewakili populasi yang bersangkutan". Dalam teori sampling dikatakan bahwa yang terkecil dan dapat mewakili distribusi normal. Sampel yang digunakan dalam penelitian ini adalah 50\% yaitu sebanyak 37 responden dari populasi 75 petani yang bergabung dalam anggota gapoktan di Gampong Kulam Ara Kecamatan Mutiara Timur.

Tabel 1. Nama Kelompok, Jumlah Anggota dan Jumlah Responden Petani yang menjadi anggota kelompok tani di Gampong Kulam Ara Kecamatan Mutiara Timur Kabupaten Pidie Tahun 2017

\begin{tabular}{clcc}
\hline No. & $\begin{array}{c}\text { Nama } \\
\text { Kelompok }\end{array}$ & $\begin{array}{c}\text { Jumlah Populasi } \\
\text { (orang) }\end{array}$ & $\begin{array}{c}\text { Jumlah Responden } \\
\text { (orang) }\end{array}$ \\
\hline 1. & Beumakmu & 25 & 13 \\
2. & Murah Hate & 25 & 12 \\
3. & Cara Tani & 25 & 12 \\
\hline \multicolumn{2}{l}{ Total } & 75 & 37 \\
\hline
\end{tabular}

Sumber: Data Primer (diolah), 2017

Data yang digunakan dalam penelitian adalah data primer dan data sekunder. Data primer adalah data yang diperoleh secara langsung saat observasi di lapangan dengan responden melalui wawancara langsung dengan pemilik tanah sedangkan data sekunder merupakan data yang diperoleh dari studi kepustakaan, instansi dan departemen terkait serta literaturnya
Metode Pengumpulan Data

Metode dalam pengumpulan data dalam penelitian ini adalah, dengan menggunakan Metode Survei. Menurut Daniel (2003) tujuan dari survei mendapatkan gambaran mewakili daerah itu dengan benar. Pada metode survei tidak semua individu di dalam populasi yang diamati, melainkan hanya suatu bagian dari populasi yang disebut sebagai contoh (sampel).

\section{Konsep dan Batasan Variabel}

Adapun konsep dan batasan terhadap variable yang digunakan dalam penelitian ini meliputi beberapa hal yaitu:

Evaluasi adalah penilaian terhadap tugas pengurus kelompok tani di daerah penelitian.

Pengurus kelompok tani adalah kontak tani dan pengurus harian kelompok tani yang diserahi tanggung jawab jawab oleh anggota kelompok untuk mengurusi kerja kelompok.

Peranan pengurus kelompok dalam musyawarah kelompok adalah perangkat perilaku dari pengurus sebagai pemimpin kelompok yang diharapkan melalui tolak ukur penilaian musyawarah kelompok.

Musyawarah kelompok tani adalah suatu kesepakatan bersama antara anggota kelompok tani untuk membicarakan ha-hal yang berhubungan dengan kebutuhan usaha taninya atau mengatasi hal-hal yang dianggapperlu.

Karakteristik petani meliputi umur, tingkat pendidikan, lama menjadi anggota kelompok tani dan luas lahan yang dimiliki oleh petani responden serta intensitas mengikuti penyuluhan.

\section{Metode Analisis}

Metode analisis data yang digunakan dalam penelitian ini adalah dengan Analisis data kuantitatif. Analisis kuantitatif adalah pendekatan ilmiah terhadap pengambilan keputusan manajerial dan ekonomi yang kemudian diproses dan menjadi informasi yang bermanfaat (Mudrajad Kunoco, 2004).

Alat analisis yang digunakan untuk menguji hipotesis yang telah dikemukakan mengenai jaringan sosial antar gapoktan dalam upaya meningkatkan pendapatan petani di Gampong Kulam Ara Kecamatan Mutiara Timur. Penelitian ini untuk menafsirkan data agar mempermudahkan dalam memperoleh data, untuk mempermudah dalam mempelajari, menganalisis dan menarik kesimpulan, data yang bersifat kualitatif penulis nyatakan dalam 
bentuk pernyataan untuk menjawab persoalan yang diteliti.

Sedangkan data yang sifatnya kuantitatif, dianalisis menggunakan rumus statistik sederhana, yaitu :

Keterangan :

$$
P=\frac{F}{N} \times 100 \%
$$

$\mathrm{P}=$ Persentase

$\mathrm{F}=$ Frekuensi

$\mathrm{N}=$ Jumlah sampel yang diambil

$100 \%$ = Angka Konstanta (Sudjana, 2009).

\section{HASIL DAN PEMBEHASAN}

\section{Gambaran Umum Lokasi Penelitian}

Berdasarkan hasil penelitian Gampong Kulam Ara merupakan salah satu gampong yang tergabung dalam Kemukiman Ujong Rimba yang terletak di sebelah timur ibu kota Kecamatan Mutiara Timur kabupaten Pidie yang jaraknya $\pm 4,5 \mathrm{~km}$ dari pusat kecamatan. Keadaan geografis Gampong Kulam Ara terletak di Kecamatan Mutiara Timur, Kabupaten Pidie, dengan: Luas wilayah $: \pm 60$ $\mathrm{H}$, persawahan $40 \mathrm{H}$ dengan batas-batas sebagai berikut:

a. Sebelah Utara : berbatasan dengan Gampong Ujong Rimba

b. Sebelah Selatan : berbatasan dengan Gampong Tring Cudo

c. Sebelah Barat : berbatasan dengan Gampong Beulangong Basah

d. SebelahTimur : berbatasan dengan Gampong Didoh

Jarak dari Gampong Kulam Ara ke Mesjid 50 M dengan jarak Gampong Kulam Ara ke SD di Gampong Didoh 500 M dan jumlah jiwa di Gampong Kulam Ara Kecamatan Mutiara Timur Kabupaten Pidie 420 jiwa dengan jumlah KK, atau $126 \mathrm{KK}$. Jarak Gampong Kulam Ara dari jalan Nasional Lintas Banda Aceh Medan 5 KM. Gampong Kulam Ara sudah sejak tahun 1930 dan nama Gampong itu sudah ada pada saat para luhur (nenek moyang) dan Bapak Muhammad Gade sebagai geuchik gampong tersebut juga tidak mengetahui sejarah nama gampong tersebut. Kondisi Umum Gampong merupakan suatu wilayah terkecil dalam stuktur pemerintahan, yang ditempati oleh sejumlah penduduk masyarakat, sebagai kesatuan masyarakat hukum yang mempunyai organisasi pemerintah di bawah camat dan mempunyai hak otonomi dalam dalam mengelola gampong sesuai dengan undang-undang No 6 Tahun 2014 tentang gampong dan undang-undang No 11 Tahun 200 tentang Pemerintahan Aceh.

Gampong Kulam Ara merupakan gampong yang berada di Kecamatan Mutiara Timur, sumber daya yang ada di Gampong Kulam Ara memiliki potensi untuk dikembangkan lebih maju, khususnya dalam bidang pertanian dimana secara fisik Gampong Kulam Ara terdiri dari persawahan, dan perkampungan yang perlu dikembangkan lebih baik dan modern sesuai dengan khazanah masyarakat dan adat istiadat yang berlaku

Sumber Daya yang ada merupakan potensi Gampong Kulam Ara sangat membantu khususnya dalam mengurangi angka penganguran dengan memaksimal pengeloaan bidang pertanian secara terpadu, konsisten dan berkelanjutan. Salah satu faktor berkembang dan majunya suatu daerah adalah jika aset yang terdapat di daerah tersebut dimanfaatkan sesuai dengan kaidah yang berlaku. Dengan tetap memperhatikan kelestarian di masyarakat yang akan datang. Gampong Kulam Ara merupakan gampong yang masih terbelakang dalam pengelolaan sumber daya dimana potensi SDM nya masih belum maksimal pemanfaatannya. Dimana hasil dari sawah masih belum mampu mengangkat kesejahteraan masyarakat yang lebih baik, dapat disaksikan perumahan masih ada yang belum layak huni, dan lingkungan yang tidak sehat. Adapun keterangan di atas merupakan wawancara dengan masyarakat setempat dan hasil pengamatan penulis.

\section{Karateristik Responden}

Responden yang dijadikan sampel dalam penelitian ini sebanyak 37 pengurus kelompok tani di Gampong Kulam Ara Kecamatan Mutiara Timur. Untuk mengetahui gambaran yang lebih jelas tentang karakteristik responden sebagaimana yang disajikan pada tabel 1 di bawah ini:

\begin{tabular}{|c|c|c|c|c|}
\hline No & & ian & $\begin{array}{l}\text { Frekuensi } \\
\text { (Orang) }\end{array}$ & $\begin{array}{l}\text { Persentase } \\
(\%)\end{array}$ \\
\hline 1. & $<30$ Tahun & & 6 & 16,2 \\
\hline 2. & $\begin{array}{l}31 \text { Tahun } \\
\text { Tahun }\end{array}$ & -40 & 11 & 29,7 \\
\hline 3. & $\begin{array}{l}41 \text { Tahun } \\
\text { Tahun }\end{array}$ & -50 & 13 & 35,1 \\
\hline 4. & $>50$ Tahun & & 7 & 19 \\
\hline \multicolumn{3}{|c|}{ Total } & 37 & 100 \\
\hline
\end{tabular}

Sumber Data Primer, 2017 (diolah)

Hasil penelitian memperlihatkan bahwa sampel yang diambil, terdapat 6 orang 
responden yang berumur 30 tahun $(16,2 \%)$, yang berumur antara 31 tahun-40 Tahun sebanyak 11 orang $(29,7 \%)$, antara 41 tahun-50 sebanyak 13 orang $(35,1 \%)$ dan berumur lebih dari 50 tahun sebanyak 7 orang (19\%). Untuk mengetahui pendidikan responden, dapat diperhatikan berikut:

Tabel 2. Pendidikan Responden di Gampong Kulam Ara Kecamatan Mutiara Timur, Tahun 2017

\begin{tabular}{clcc}
\hline No & Uraian & $\begin{array}{c}\text { Frekuensi } \\
\text { (Orang) }\end{array}$ & $\begin{array}{c}\text { Persentase } \\
(\%)\end{array}$ \\
\hline 1. & SD & 7 & 18,9 \\
2. & SMP & 17 & 45,9 \\
3. & SMA & 13 & 32,2 \\
4. & Perguruan & 0 & 0.0 \\
& Tinggi & & 100 \\
\hline & Total & 37 & \\
\hline
\end{tabular}

Sumber Data Primer, 2017 (diolah)

Berdasarkan tabel di atas, maka yang berpendidikan SD sebanyak 7 orang $(45,9 \%)$, SMP sebanyak 17 orang (45,9\%), SMA sebanyak 13 orang $(32,2 \%)$ sehingga dapat dikatakan bahwa pendidikan responden pada umumnya berpendidkan SMA. Adapun untuk mengetahui jumlah tanggungan responden dalam penelitian, maka dapat diperhatikan pada tabel berikut:

Tabel 3. Jumlah Tanggungan Responden di Gampong Kulam Ara Kecamatan Mutiara Timur, Tahun 2017

\begin{tabular}{clcc}
\hline No & Uraian & $\begin{array}{c}\text { Frekuensi } \\
\text { (Orang) }\end{array}$ & $\begin{array}{c}\text { Persentase } \\
(\%)\end{array}$ \\
\hline 1. & $\begin{array}{l}1-3 \\
\text { Orang }\end{array}$ & 11 & 29,7 \\
2. & $\begin{array}{l}4-6 \\
\text { Orang }\end{array}$ & 19 & 51,3 \\
3. & $7-9$ & 7 & 19 \\
4. & $\begin{array}{l}\text { Orang } \\
\text { 7 }\end{array}$ & 0 & 0,0 \\
\hline \multicolumn{4}{c}{ Total } \\
\hline
\end{tabular}

Sumber Data Primer, 2017 (diolah)

Keterangan tabel di atas, maka jumlah tanggungan antara 1-3 orang sebanyak 11 orang (29,7\%), antara 4-6 orang sebanyak 19 orang $(51,3 \%)$ dan antara 7-9 sebanyak 7 orang (19\%). Sedangkan untuk mengetahui luas lahan pertanian dapat diperhatikan pada tabel berikut:

Tabel 4. Luas Lahan Responden di Gampong Kulam Ara Kecamatan Mutiara Timur, Tahun 2017

\begin{tabular}{cccc}
\hline No & Uraian & $\begin{array}{c}\text { Frekuensi } \\
\text { (Orang) }\end{array}$ & Persentase (\%) \\
\hline 1. & $0,25 \mathrm{Ha}$ & 18 & 48,6
\end{tabular}

\begin{tabular}{cccc} 
2. & $0,50 \mathrm{Ha}$ & 10 & 27,0 \\
3. & $>0,50 \mathrm{Ha}$ & 9 & 24,4 \\
\hline & Total & 37 & 100 \\
\hline
\end{tabular}

Sumber Data Primer, 2017 (diolah)

Berdasarkan tabel di atas, maka luas lahan respoden di Gampong Kulam Ara Kecamatan Mutiara Timur, yang memiliki luas lahan 0,25 Ha sebanyak 18 orang $(48,6 \%)$ dan yang memiliki luas lahan lebih dari 0,50 Ha sebanyak 10 orang $(27,0 \%)$ dan 9 orang $(24,4 \%)$ memiliki $>0,50 \mathrm{Ha}$. Dari jumlah responden yang dijadikan sampel dalam penelitian ini, sehingga berdasarkan umur, pendidikan, jumlah tanggungan dan luas lahan dapat membentuknya kelompok tani agar meningkatkan pemberdayaan masyarakat petani.

Survey Kepuasan Anggota Gapoktan Terhadap Peran Pengurus dalam Pelaksanaan Musyawarah Kelompok Tani di Gampong Kulam Ara Kecamatan Mutiara Timur Kabupaten Pidie

Berdasarkan hasil penelitian tentang survey kepuasan anggota gapoktan terhadap peran pengurus dalam pelaksanaan musyawarah kelompok tani terdapat perkembangan kelompok tani di Gampong Kulam Ara Kecamatan Mutiara Timur Kabupaten Pidie dalam hal pertambahan jumlah anggota kelompok tani, jumlah kelompok tani dan jumlah penyuluh yang bertugas adalah relatip tetap. Secara umum karakteristik petani sampel di daerah penelitian adalah berumur produktif antara 41 tahun sampai 50 tahun, menempuh pendidikan sekolah menengah tingkat pertama, lamanya menjadi anggota adalah 6 tahun dengan luas lahan 0,52 Ha. Penilaian anggota kelompok tani terhadap peran pengurus dalam pelaksanaan musyawarah kelompok tani berada pada kategori sedang dan sangat baik.

Anggota kelompok tani di Gampong Kulam Ara Kecamatan Mutiara Timur menilai pelaksanaan musyawarah kelompok tani baik dan terdapat nilai yang sangat signifikan antara penilaian anggota kelompok tani terhadap pelaksanaan 
musyawarah kelompok tani di tiga kelompok sampel penelitian.

Baik tidaknya peran pengurus dalam pelaksaan musyawarah kelompok tani di Gampong Kulam Ara Kecamatan Mutiara Timur Kabupaten Pidie dapat dilihat dari tingkat kesetujuan responden selaku anggota gapoktan atas pernyataan yang terdapat di dapat kuesioner yang telah disebarkan sebelumnya. Untuk mengetahui sejauh mana intensitas mengikuti rapat anggota dalam satu tahun terakhir, dapat dilihat pada tabel berikut:

Tabel 5. Intensitas mengikuti rapat anggota dalam satu tahun terakhir

\begin{tabular}{llcc}
\hline No & $\begin{array}{l}\text { Alternatif } \\
\text { Jawaban }\end{array}$ & $\begin{array}{c}\text { Frekuensi } \\
(\mathrm{F})\end{array}$ & $\begin{array}{c}\text { Persentase } \\
(\%)\end{array}$ \\
\hline a. & $3 \mathrm{Kali}$ & 14 & 37,8 \\
b. & 4 Kali & 7 & 18,9 \\
c. & $5 \mathrm{Kali}$ & 6 & 16,2 \\
d. & $>$ 5 Kali & 10 & 27,1 \\
\hline & Jumlah & 37 & 100 \\
\hline
\end{tabular}

Sumber Data Primer, 2017 (diolah)

Berdasarkan keterangan di atas, maka mayoritas menjawab bahwa intensitas mengikuti rapat anggota dalam satu tahun terakhir tiga kali sebanyak 14 orang $(37,8 \%)$ dan sebagian kecil responden menjawab bahwa intersitas mengikuti rapat anggota dalam satu tahun terakhir 5 kali sebanyak 6 orang $(16,2 \%)$.

Alasan memiliki intensitas mengikuti rapat anggota dalam satu tahun terakhir sebanyak 3 kali, karena perlunya mengikuti rapat anggota untuk meningkatkan kerja sama antar kelompok tani, dengan meningkatnya kerja sama dapat meningkatkan mekanisme dalam bekerja sehingga mampu meningkatkan produksi petani serta mampu meningkatkan pendpaatan petani pada umumnya khususnya dalam kelompok tani di Gampong Kulam Ara Kecamatan Mutiara Timur Kabupaten Pidie.

Untuk mengetahui paran anggota dalam mengajukan usul atau pendapat, maka dapat diperhatikan pada tabel berikut:

Tabel 6. Intesitas usul/pendapat tentang kelompok tani di daerah Penelitian Tahun 2017

\begin{tabular}{llcc}
\hline No & $\begin{array}{l}\text { Alternatif } \\
\text { Jawaban }\end{array}$ & $\begin{array}{c}\text { Frekuensi } \\
(\mathrm{F})\end{array}$ & $\begin{array}{c}\text { Persentase } \\
(\%)\end{array}$ \\
\hline a. & Selalu & 4 & 10,8 \\
b. & Kadang- & 23 & 62,1 \\
& kadang & &
\end{tabular}

\begin{tabular}{llll} 
c. & Tidak Pernah & 10 & 27,1 \\
\hline Jumlah & 37 & 100
\end{tabular}

Sumber Data Primer, 2017 (diolah)

Berdasarkan tabel di atas, maka mayoritas responden menjawab bahwa kadang-kadang mengajukan usul/pendapat $(62,1 \%)$ dan sebagian kecil menjawab selalu mengajukan usul/pendapat $(10,8 \%)$.

Alasan mengajukan usul/pendapat agar mampu melaksanakan musyawarah kelompok tani dengan baik berdasarkan hasil ditemukan dalam sehari-hari, dapat mengetahui maksud dari ide yang diusulkan oleh masing-masing kelompok tani secara keseluruhan melalui usulan pendapat para kelompok tani mampu mengembangkan usahatani dengan baik, sehingga dapat meningkatkan produksi usahatani. Untuk mengetahui ada tidaknya mengikuti rapat kelompok, maka dapat diperhatikan pada tabel berikut:

Tabel 7. Mengikuti rapat kelompok tentang kelompok tani di daerah Penelitian Tahun 2017

\begin{tabular}{llcc}
\hline No & $\begin{array}{l}\text { Alternatif } \\
\text { Jawaban }\end{array}$ & Frekuensi (F) & $\begin{array}{c}\text { Persentase } \\
(\%)\end{array}$ \\
\hline a. & Selalu ikut & 15 & 40,5 \\
b. & $\begin{array}{l}\text { Kadang- } \\
\text { kadang }\end{array}$ & 19 & 51,3 \\
c. & $\begin{array}{l}\text { Tidak pernah } \\
\text { mengikuti }\end{array}$ & 3 & 8,2 \\
\hline & Jumlah & 37 & 100 \\
\hline
\end{tabular}

Sumber Data Primer, 2017 (diolah)

Berdasarkan tabel di atas, dominan jawaban responden menjawab kadang-kadang mengikuti rapat kelompok sebanyak 19 orang $(51,3 \%)$ dan sebagian kecil responden menjawab bahwa tidak pernah mengikuti rapat kelompok.

Alasan kadang-kadang mengikuti rapat kelompok karena sibuk dengan pekerjaan lain, sehingga tidak dapat mengikuti setiap rapat kelompok tani di Kecamatan Mutiara Timur dan selalu mengikuti karena merasa rapat salah satu kegiatan yang penting, agar mengetahui prosedur dari kinerja kelompok tani di Kecamatan Mutiara Timur Kabupaten Pidie. Untuk mengetahui responden bersedia menjadi pengurus, dapat diperhatikan pada tabel berikut:

Tabel 8. Bersedia menjadi pengurus kelompok tani di daerah Penelitian Tahun 2017

\begin{tabular}{llcc}
\hline No & $\begin{array}{l}\text { Alternatif } \\
\text { Jawaban }\end{array}$ & $\begin{array}{l}\text { Frekue } \\
\text { nsi (F) }\end{array}$ & $\begin{array}{c}\text { Persentase } \\
(\%)\end{array}$ \\
\hline a. & $\begin{array}{l}\text { Selalu bersedia } \\
\text { dengan jabatan } \\
\text { apa saja }\end{array}$ & 10 & 27,0 \\
& & & \\
& & & \\
\end{tabular}




\begin{tabular}{llcc} 
b. & $\begin{array}{l}\text { Kadang-kadang } \\
\text { bersedia dengan } \\
\text { jabatan tertentu }\end{array}$ & 15 & 40,5 \\
c. $\quad \begin{array}{l}\text { Menjadi anggota } \\
\text { saja }\end{array}$ & 12 & 32,5 \\
\hline & 37 & 100 \\
\hline
\end{tabular}

Sumber Data Primer, 2017 (diolah)

Berdasarkan keterangan tabel diatas, mayoritas responden menjawab bahwa kadangkadang bersedia dengan jabatan tertentu sebanyak 15 orang $(40,5 \%)$ dan sebagian kecil menjawab selalu bersedia dengan jabatan apa saja 10 orang $(27 \%)$ selalu bersedia dengan jabatan apa saja.

Alasan selalu bersedia dengan jabatan apa saja karena suka menjadi pengurus dalam setiap kegiatan dan alasan kadang-kadang bersedia menjadi pengurus di kelompok tani agar dapat meningkatkan kegiatan petani dengan meningkatkan kegiatan maka produksi hasil pertanian juga bertambah serta alasan menajdi anggota saja karena tidak suka menjadi pengurus dan tidak ada kemampuan.

Untuk mengetahui termasuk anggota yang aktif, maka dapat diperhatikan pada tabel berikut:

Tabel 9. Termasuk anggota yang aktif kelompok tani di daerah Penelitian Tahun 2017

\begin{tabular}{llcc}
\hline No & $\begin{array}{l}\text { Alternatif } \\
\text { Jawaban }\end{array}$ & $\begin{array}{c}\text { Frekuensi } \\
(\mathrm{F})\end{array}$ & $\begin{array}{c}\text { Persentase } \\
(\%)\end{array}$ \\
\hline a. & Ya & 20 & 54,0 \\
b. & Biasa saja & 15 & 40,5 \\
c. & Tidak & 2 & 5,5 \\
\hline & Jumlah & 37 & 100 \\
\hline
\end{tabular}

Sumber Data Primer, 2017 (diolah)

Keterangan tabel diatas lebih dominan menjawab ya karena mayoritas responden aktif dalam kelompok tani sebanyak 20 orang (54\%) dan sebagian kecil responden menjawab tidak aktif sebanyak 2 orang (5,5\%).

Alasan menjawab aktif karena respoden berprofesi sebagai petani, dan menarik untuk bergabung dalam kelompok tani dapat menambah informasi, pengalaman dan wawasan sehingga memahami tata cara bertani yang baik dan benar yang mampu meningkatkan produksi dalam bertani dan ada pula tidak aktif ada bekerja di tempat lain selain bertani.

Untuk mengetahui kendala selama mengikuti kegiatan, maka dapat diperhatikan pada tabel berikut:
Tabel 10. Kendala selama mengikuti kegiatan tentang kelompok tani di daerah Penelitian Tahun 2017

\begin{tabular}{llcc}
\hline No & $\begin{array}{l}\text { Alternatif } \\
\text { Jawaban }\end{array}$ & $\begin{array}{c}\text { Frekuensi } \\
(\mathrm{F})\end{array}$ & $\begin{array}{c}\text { Persentase } \\
(\%)\end{array}$ \\
\hline a. & Ada & 20 & 54,0 \\
b. & Kadang- & 15 & 40,5 \\
& kadang & & 5,5 \\
c. & Tidak ada & 2 & 100 \\
\hline & Jumlah & 37 & \\
\hline
\end{tabular}

Sumber Data Primer, 2017 (diolah)

Berdasarkan tabel diatas maka mayoritas responden dalam penelitian ini menjawab bahwa ada kendala selama mengikuti kegiatan sebanyak 20 orang (54\%), dan menjawab tidak ada kendala selama mengikuti kegiatan sebanyak 2 orang $(5,5 \%)$.

Alasan menjawab ada kendala selama mengikuti kegiatan karena mendapatkan tidak mencukupi modal, kurangnya tenaga kerja, dan adanya kesibukan lain selain bertani yang menjawab kadang-kadang beralasan tidak mencukupi modal dan sarana untuk bekerja dan menjawab tidak ada karena dapat mencukupi modal dan tenaga kerja.

Untuk mengetahui intensitas mengikuti pertemuan kelompok tani, maka dapat diperhatikan pata tabel berikut:

Tabel 11. Intensitas mengikuti pertemuan kelompok tani di daerah penelitian

\begin{tabular}{llcc}
\hline No & $\begin{array}{l}\text { Alternatif } \\
\text { Jawaban }\end{array}$ & Frekuensi (F) & $\begin{array}{c}\text { Persentase } \\
(\%)\end{array}$ \\
\hline a. & Selalu & 10 & 27,0 \\
b. & Kadang- & 27 & 73 \\
& kadang & & 0,0 \\
c. & Tidak ada & 0 & 100 \\
\hline & Jumlah & 37 &
\end{tabular}

Sumber Data Primer, 2017 (diolah)

Keterangan tabel di atas, maka sebagian besar responden dalam penelitian ini menjawab bahwa kadang-kadang mengikuti petemuan kelompok tani sebanyak 27 orang $(73 \%)$, dan sebagian kecil menjawab selalu mengikuti pertemuan kelompok tani sebanyak 10 orang $(27 \%)$.

Alasan menjawab kadang-kadang karena berhalangan atau sibuk dengan kegiatan lainnya sehingga tidak sempat mengikuti rapat anggota kelompok tani dan alasan menjawab selalu karena merasa musyawarah penting untuk meningkatkan kebersamaan sesama anggota kelompok tani. 
Untuk mengetahui jumlah kegiatan dalam setahun, dapat diperhatikan pada tabel berikut:

Tabel 12. Jumlah kegiatan dalam setahun di kelompok tani Gampong Kulam Ara Kecamatan Mutiara Timur, Tahun 2017

\begin{tabular}{llcc}
\hline No & $\begin{array}{l}\text { Alternatif } \\
\text { Jawaban }\end{array}$ & $\begin{array}{c}\text { Frekuensi } \\
(\mathrm{F})\end{array}$ & $\begin{array}{c}\text { Persentase } \\
(\%)\end{array}$ \\
\hline a. & $\begin{array}{l}\text { Lebih dari } \\
\text { kegiatan }\end{array}$ & 3 & 8,1 \\
b. & $\begin{array}{l}\text { Hanya 1- } \\
\text { kegiatan } \\
\text { c. }\end{array}$ & 27 & 72,9 \\
\hline & Tidak ada & 7 & 19 \\
\hline
\end{tabular}

Sumber Data Primer, 2017 (diolah)

Berdasarkan tabel diatas, maka mayoritas responden menjawab bahwa hanya 1-3 kegiatan dalam setahun sebanyak 27 orang $(72,9 \%)$ dan sebagian kecil menjawab jumlah kegiatan dalam setahun lebih dari 3 kegiatan sebanyak 3 orang $(8,1 \%)$.

Alasan menjawab hanya 1-3 kegiatan karena yang dikuti hanya 1 sampai 3 kegiatan dalam setahun dan rata-rata kegiatan petani di Gampong Kulam Ara Kecamatan Mutiara Timur berprofesi sebagai petani padi sawah dan yang menjawab tidak ada karena tidak pernah mengikuti kegiatan kelompok tani dan menjawab lebih dari 3 kegiatan karena sering mengikuti kegiatan.

Untuk mengetahui kesulitan dalam mengajak kelompok tani melakukan kegiatan, maka dapat diketahui pada tabel berikut:

Tabel 13. Kesulitan dalam mengajak kelompok tani melakukan kegiatan

\begin{tabular}{llcc}
\hline No & $\begin{array}{l}\text { Alternatif } \\
\text { Jawaban }\end{array}$ & $\begin{array}{c}\text { Frekuensi } \\
\text { (F) }\end{array}$ & Persentase (\%) \\
\hline a. & $\begin{array}{l}\text { Tidak } \\
\text { pernah }\end{array}$ & 0 & 0,0 \\
b. & $\begin{array}{l}\text { Kadang- } \\
\text { kadang }\end{array}$ & 12 & 32,4 \\
c. & Pernah & 25 & 67,6 \\
\hline & Jumlah & 37 & 100 \\
\hline
\end{tabular}

Sumber Data Primer, 2017 (diolah)

Berdasarkan tabel diatas, maka mayoritas menajwab bahwa kesulitan dalam mengajak kelompok tani melakukan kegiatan sebanyak 25 orang $(67,6 \%)$ dan sebagian kecil responden menjawab bahwa kadang-kadang kesulitan dalam mengajak kelompok tani melakukan kegiatan sebanyak 12 orang $(32,4 \%)$.

Alasan menjawab pernah karena sering mengalami kesulitan dalam mengajak kelompok tani melakukan kegiatan mengalami kesulitan

mengajak kelompok tani melakukan kegiatan karena masing-masing kelompok tani memiliki kesibukan masing-masing dalam sehari-hari, sehingga memiliki kesulitan untuk mengajak kelompok tani melakukan kegiatan yang berkaitan dengan kelompok tani.

Untuk mengetahui bentuk kerja sama dalam melaksanakan kegiatan dapat diperhatikan pada tabel berikut:

Tabel 14. Bentuk kerja sama dalam melaksanakan kegiatan kelompok tani

\begin{tabular}{llcc}
\hline No & $\begin{array}{l}\text { Alternatif } \\
\text { Jawaban }\end{array}$ & $\begin{array}{c}\text { Frekuensi } \\
(\mathrm{F})\end{array}$ & $\begin{array}{c}\text { Persentase } \\
(\%)\end{array}$ \\
\hline a. & $\begin{array}{l}\text { Dilakukan } \\
\text { secara bersama }\end{array}$ & 33 & 89,1 \\
b. & $\begin{array}{l}\text { Dilakukan } \\
\text { individual/sen } \\
\text { diri }\end{array}$ & 4 & 10,9 \\
c. & $\begin{array}{l}\text { Tidak ada } \\
\text { kerja sama }\end{array}$ & 0 & 0,0 \\
\hline & Jumlah & 37 & 100 \\
\hline
\end{tabular}

Sumber Data Primer, 2017 (diolah)

Berdasarkan tabel di atas, maka mayoritas responden menjawab bahwa bentuk kerja sama dalam melaksanakan kegiatan dilakukan secara bersama sebanyak 33 orang $(89,1 \%)$ dan sebagian kecil menjawab bahwa dilakukan individual/sendiri sebanyak 4 orang $(10,9 \%)$.

Alasan melakukan secara bersama karena dapat meningkatkan kesatuan antar anggota gapoktan, dengan bekerja sama semua bentuk pekerjaan yang berat akan terasa ringan akibat adanya kebersamaan dalam bekerja, melalui kebersamaan mampu meningkatkan produksi usahatani di Kecamatan Mutiara Timur Kabupaten Pidie, alasan dilakukan secara individual/sendiri karena dapat dilakukan sendiri dalam bentuk kerja yang ringan.

Untuk mengetahui intensitas dalam sebulan mengikuti program penyuluhan pertanian, maka dapat diperhatikan pada tabel berikut:

Tabel 15. Intensitas dalam sebulan mengikuti program penyuluhan pertanian

\begin{tabular}{llcc}
\hline No & $\begin{array}{l}\text { Alternatif } \\
\text { Jawaban }\end{array}$ & $\begin{array}{c}\text { Frekuensi } \\
(\mathrm{F})\end{array}$ & $\begin{array}{c}\text { Persentase } \\
(\%)\end{array}$ \\
\hline a. & $\begin{array}{l}2 \text { kali dalam } \\
\text { satu bulan }\end{array}$ & 3 & 8,1 \\
b. & $\begin{array}{l}1-2 \text { kali satu } \\
\text { bulan }\end{array}$ & 32 & 86,4 \\
c. & Tidak pernah & 2 & 5,5
\end{tabular}




\begin{tabular}{lll}
\hline Jumlah & 37 & 100
\end{tabular}

\section{Sumber Data Primer, 2017 (diolah)}

Berdasarkan tabel di atas, maka sebagian besar responden menjawab bahwa 1-2 kali dalam satu bulan mengikuti program penyuluhan pertanian di Gampong Kulam Ara Kecamatan Mutiara Timur Kabupaten Pidie $(8,1 \%)$, dan sebagian kecil menjawab 2 kali $(5,5 \%)$ dalam satu bulan mengikuti program penyuluhan peertanian dan sebagian kecil menjawab tidak pernah mengikuti.

Alasan 1-2 kali dalam satu bulan mengikuti program penyuluhan pertanian karena sering mengikutinya program penyuluhan pertanian sebanyak 1 samapi 2 kali dalam sebulan dan alasan tidak pernah karena tidak pernah mengikutinya disebabkan kurangnya pengetahuan tentang program penyuluhan pertanian.

Untuk mengetahui selalu aktif mengajukan usul atau pertanyaan, dapat diperhatikan pada tabel berikut:

Tabel 16. Selalu aktif mengajukan usul atau pertanyaan di kelompok tani

\begin{tabular}{|c|c|c|c|}
\hline No & $\begin{array}{l}\text { Alternatif } \\
\text { Jawaban }\end{array}$ & $\begin{array}{l}\text { Frekuensi } \\
\text { (F) }\end{array}$ & $\begin{array}{c}\text { Persentase } \\
(\%)\end{array}$ \\
\hline a. & $\begin{array}{l}\text { Aktif } \\
\text { mengajukan } \\
\text { usul }\end{array}$ & 7 & 18,9 \\
\hline b. & $\begin{array}{l}\text { Kurang aktif } \\
\text { dalam bertanya }\end{array}$ & 26 & 70,2 \\
\hline c. & $\begin{array}{l}\text { Aktif (diam } \\
\text { dan } \\
\text { mendengar) }\end{array}$ & 4 & 10,8 \\
\hline & Jumlah & 37 & 100 \\
\hline
\end{tabular}

Sumber Data Primer, 2017 (diolah)

Berdasarkan tabel di atas, maka mayoritas responden menjawab bahwa kurang aktif dalam bertanya sebanyak 26 orang $(70,2 \%)$ dan sebagai kecil menjawab bahwa aktif (diam dan mendengar) sebanyak 4 orang $(10,8 \%)$.

Alasan banyaknya anggota yang kurang aktif bertanya karena tidak memiliki keberanian dalam mengungkapkan pendapat, ide dan gagasan ketika bermusyawarah, sulit dalam mengeluarkan ide akibat kekurangan pengetahuan dan wawasan dari kelompok tani dalam musyawarah kelompok tani pada umumnya anggota kelompok tidak aktif dalam mengajukan usul tidak memiliki keberanian dalam rapat dan aktif (diam mendengar) karena yang disampaikan dalam rapat tidap perlu dikritik dan diberikan usul.
Untuk mengetahui pernah mengikuti pelatihan demi kemajuan kelompok, maka dapat diperhatikan pada tabel berikut:

Tabel 17. Pernah mengikuti pelatihan demi kemajuan kelompok tani

\begin{tabular}{llcc}
\hline No & $\begin{array}{l}\text { Alternatif } \\
\text { Jawaban }\end{array}$ & $\begin{array}{c}\text { Frekuensi } \\
(\mathrm{F})\end{array}$ & $\begin{array}{c}\text { Persentase } \\
(\%)\end{array}$ \\
\hline a. & Ya & 15 & 40,5 \\
b. & Kadang- & 20 & 54,0 \\
& kadang & & \\
c. & Tidak pernah & 2 & 5,5 \\
\hline & Jumlah & 37 & 100 \\
\hline
\end{tabular}

Sumber Data Primer, 2017 (diolah)

Berdasarkan tabel di atas, maka mayoritas responden menjawab bahwa kadang-kadang pernah mengikuti pelatihan demi kemajuan kelompok sebanyak $(54,0 \%)$ dan sebagian kecil menjawab bahwa tidak pernah mengikuti pelatihan demi kemajuan kelompok sebanyak 2 orang $(5,5 \%)$.

Alasan menjawab kadang-kadang karena tidak sering mengikuti pelatihan demi kemajuan kelompok untuk meningkatkan pengetahuan pertanian mengenai program penyuluhan yang akan dikembangkan oleh gapoktan, oleh sebab itu pihak kelompok tani tidak sering mengikuti pelatihan akibat kurangnya program pelatihan yang diberikan kepada petani di Gampong Kulam Ara oleh Pemerintah Kabupaten Pidie.

Untuk mengetahui minat mengikuti program penyuluhan, maka dapat diperhatikan pada tabel berikut:

Tabel 18. Minat mengikuti program penyuluhan kelompok tani di daerah penelitian, Tahun 2017

\begin{tabular}{llcc}
\hline No & $\begin{array}{l}\text { Alternatif } \\
\text { Jawaban }\end{array}$ & $\begin{array}{c}\text { Frekuensi } \\
(\mathrm{F})\end{array}$ & $\begin{array}{c}\text { Persentase } \\
(\%)\end{array}$ \\
\hline a. & $\begin{array}{l}\text { Sangat } \\
\text { berminat }\end{array}$ & 8 & 21,6 \\
b. & $\begin{array}{l}\text { Kadang-kadang } \\
\text { tergantung } \\
\text { topik }\end{array}$ & 29 & 78,4 \\
c. & Tidak berminat & 0 & 0,0 \\
\hline & Jumlah & 37 & 100 \\
\hline
\end{tabular}

Sumber Data Primer, 2017 (diolah)

Keterangan tabel di atas dapat terlihat mayoritas minat mengikuti program penyuluhan kadang-kadang tergantung topik sebanyak 29 orang $(78,4 \%)$, dan sebagian kecil responden menjawab bahwa sangat berminat sebanyak 8 orang $(21,6 \%)$.

Alasan menjawab kadang-kadang tergantung topik karena jika topiknya tidak menarik dan sudah memahami maka minat 
untuk mengikuti program penyuluhan tersebut menjadi berkurang dan pengaruh dari pembawa materi dari program penyuluhan yang diberikan kepada petani pada umumnya khususnya di Gampong Kulam Ara Kecamatan Mutiara Timur Kabupaten Pidie dan alasan menjawab sangat berminat karena program penyuluhan sebagai sumber ilmu pengetahuan bagi petani pada umumnya.

Untuk mengetahui program yang berjalan selama ini sudah sesuai kebutuhan, dapat diperhatikan pada tabel berikut:

Tabel 19. Program yang berjalan selama ini sudah sesuai kebutuhan kelompok tani

\begin{tabular}{llcc}
\hline No & $\begin{array}{l}\text { Alternatif } \\
\text { Jawaban }\end{array}$ & $\begin{array}{c}\text { Frekuensi } \\
(\mathrm{F})\end{array}$ & $\begin{array}{c}\text { Persentase } \\
(\%)\end{array}$ \\
\hline a. & Ya & 8 & 21,6 \\
b. & Kadang- & 29 & 51,4 \\
& kadang & & 0,0 \\
c. & Tidak & 0 & 100
\end{tabular}

Sumber Data Primer, 2017 (diolah)

Berdasarkan tabel diatas maka lebih dominan jawaban responden tentang program yang berjala selama ini sudah sesuai kebutuhan sebanyak 29 orang $(78,4 \%)$ dan sebagain kecil menjawab bahwa program yang berjalan selama ini sudah sesuai kebutuhan sebanyak 8 orang $(21,6 \%)$.

Alasan responden menjawab kadangkadang program yang berjalan ini sudah sesuai kebutuhan karena berdasarkan hasil pengamatan peneliti dan wawancara dengan petani di kelompok tani bawah sesuai dengan kebutuhan masyarakat petani di Gampong Kulam Ara Kecamatan Mutiara Timur dan alasan menjawab ya karena program yang dijalankan sesuai kebutuhan.

Untuk mengetahui inisiatif mencari informasi terbaru, maka dapat diperhatikan pada tabel berikut:

Tabel 20. Inisiatif mencari informasi terbaru untuk kelompok tani di daerah penelitian, Tahun 2017

\begin{tabular}{llcc}
\hline No & $\begin{array}{l}\text { Alternatif } \\
\text { Jawaban }\end{array}$ & $\begin{array}{c}\text { Frekuensi } \\
(\mathrm{F})\end{array}$ & $\begin{array}{c}\text { Persentase } \\
(\%)\end{array}$ \\
\hline a. & $\begin{array}{l}\text { Mendatangkan } \\
\text { petugas } \\
\text { penyuluh }\end{array}$ & 13 & 35,1 \\
b. & $\begin{array}{l}\text { Bertanya pada } \\
\text { anggota lain }\end{array}$ & 23 & 62,1 \\
c. & $\begin{array}{l}\text { Tidak ada } \\
\text { inisiatif }\end{array}$ & 1 & 2,8
\end{tabular}

\begin{tabular}{l}
\hline Jumlah \\
Sumber Data Primer, 2017 (diolah) \\
Berdasarkan tabel di atas, maka sebagian \\
besar responden dalam penelitian ini menjawab \\
bahwa inisiatif mencari informasi terbaru \\
dengan bertanya pada anggota lain sebanyak 23 \\
orang $(62,1 \%)$ dan sebagian kecil menjawab \\
bahwa yang tidak memiliki inisiatif hanya 1 \\
orang $(2,8 \%)$.
\end{tabular}

Alasan cara atau inisiatif mencari informasi baru dengan bertanya pada anggota lain menjadi solusi yang sangat mudah untuk mencari informasi terbaru, melalui bertanya petani dapata mengetahui hal-hal baru untuk meningkatkan program tanam yang baik dan benar dan meningkatkan produksi petani. Alasan mendatangkan petugas penyuluh supaya informasi yang terbaru akan lebih akurat dan yang tidak memiliki inisiatif disebabkan kurang aktif di kelompok tani.

Untuk mengetahui yang mencari informasi dari luar untuk kegiatan kelompok, dapat diperhatikan pada tabel berikut:

Tabel 21. Mencari informasi dari luar untuk kegiatan kelompok di daerah penelitian, Tahun 2017

\begin{tabular}{llcc}
\hline No & $\begin{array}{l}\text { Alternatif } \\
\text { Jawaban }\end{array}$ & $\begin{array}{l}\text { Frekue } \\
\text { nsi }(\mathrm{F})\end{array}$ & $\begin{array}{c}\text { Persentase } \\
(\%)\end{array}$ \\
\hline a. & $\begin{array}{l}\text { Hanya dilakukan } \\
\text { oleh ketua }\end{array}$ & 21 & 56,7 \\
b. & $\begin{array}{l}\text { Dilakukan } \\
\text { bersama } \\
\text { kelompok } \\
\text { Tidak dilakukan } \\
\text { sama sekali }\end{array}$ & 16 & 43,3 \\
c. 0 & 0, \\
\hline & Jumlah & 37 & 100 \\
\hline
\end{tabular}

Sumber Data Primer, 2017 (diolah)

Berdasarkan tabel di atas, responden lebh dominan menjawab yang mencari informasi dari luar untuk kegiatan kelompok hanya dilakukan oleh ketua sebanyak 21 orang $(56,7 \%)$ dan sebagian kecil menjawab kecil menjawab dilakukan bersama kelompok sebanyak 16 orang $(43,3 \%)$.

Alasan yang mencari informasi dari luar untuk kegiatan kelompok hanya dilakukan oleh ketua karena ketua banyak mengenai jaringan sosial di luar kelompok tani, lebih memahami masalah atau informasi, ketua lebih bertanggung jawab terhadap program kerja yang dilakukan oleh kelompok tani pada umumnya dan khususnya di Gampong Kulam Ara Kecamatan Mutiara Timur Kabupaten Pidie dan alasan dilakukan bersama kelompok agar mampu 
meningkatkan kebersamaan antar kelompok tani di Gampong Kulam Ara Kecamatan Mutiara Timur Kabupaten Pidie.

Untuk mengetahui cara penyampaian informasi baru dari PPL kepada petani, dapat diperhatikan pada tabel berikut:

Tabel 22. Cara penyampaian informasi baru dari PPL kepada petani di daerah penelitian, Tahun 2017

\begin{tabular}{clcc}
\hline No & $\begin{array}{l}\text { Alternatif } \\
\text { Jawaban }\end{array}$ & $\begin{array}{c}\text { Frekuensi } \\
(\mathrm{F})\end{array}$ & $\begin{array}{c}\text { Persentase } \\
(\%)\end{array}$ \\
\hline a. & Secara lisan & 33 & 89,1 \\
b. & $\begin{array}{l}\text { Melalui } \\
\text { program }\end{array}$ & 2 & 5,45 \\
c. & $\begin{array}{l}\text { Melalui } \\
\text { Selebaran }\end{array}$ & 2 & 5,45 \\
\hline & Jumlah & 37 & 100 \\
\hline
\end{tabular}

Sumber Data Primer, 2017 (diolah)

Berdasarkan tabel di atas, maka mayoritas responden menjawab bahwa cara penyampaian informasi baru dari PPL kepada petani sebanyak 33 orang $(89,1 \%)$ dan sebagian kecil menjawab bahwa melalui selebaran sebanyak 2 orang $(5,45 \%)$.

Alasan menjawab cara penyampaian informasi baru dari PPL kepada petani secara lisan karena mudah dalam menyampaikan kepada petani, alasan melalui program agar dapat terkumpul semua anggota kelompok tani. Alasan cara penyampaian informasi baru dari PPL kepada petani melalui selebaran karena dapat ditempel di papan informasi.

Untuk mengetahui kesulitan dalam menerima informasi baru, dapat diperhatikan pada tabel berikut:

Tabel 23. Kesulitan dalam menerima informasi baru di kelompok tani di daerah penelitian, Tahun 2017

\begin{tabular}{llcc}
\hline No & $\begin{array}{l}\text { Alternatif } \\
\text { Jawaban }\end{array}$ & $\begin{array}{c}\text { Frekuensi } \\
(\mathrm{F})\end{array}$ & $\begin{array}{c}\text { Persentase } \\
(\%)\end{array}$ \\
\hline a. & $\begin{array}{l}\text { Tidak } \\
\text { pernah }\end{array}$ & 9 & 24,3 \\
b. & $\begin{array}{l}\text { Kadang- } \\
\text { kadang }\end{array}$ & 26 & 70,2 \\
c. & $\begin{array}{l}\text { Jarang } \\
\text { sekali }\end{array}$ & 2 & 5,5 \\
\hline & Jumlah & 37 & 100 \\
\hline
\end{tabular}

Sumber Data Primer, 2017 (diolah)

Berdasarkan tabel di atas, mayoritas responden dalam penelitian ini menjawab bahwa kadang-kadang kesulitan dalam menerima informasi baru $(70,2 \%)$ dan sebagian kecil menjawab jarang sekali $(5,5 \%)$.
Alasan kadang-kadang kesulitan dalam menerima informasi baru karena informasi baru belum tentu akurat, atau benar apabila sering adanya informasi penipuan tidak pernah mendapatkan kesulitan dalam informasi baru karena tidak pernah mendapat informasi yang tidak benar. Informasi yang baru biasanya sering menimbulkan masalah terhadap kelompok tani pada umumnya dan khusus di Gampong Kulam Ara Kecamatan Mutiara Timur Kabupaten Pidie, sedangkan alasan menjawab jarang sekali karena kurang mendapatkan informasi baru dalam kelompok tani.

Untuk mengetahui bahasa anggota penyuluh mudah dipahami, dapat diperhatikan pada tabel berikut:

Tabel 24. Bahasa anggota penyuluh mudah dipahami di kalangan kelompok tani

\begin{tabular}{llcc}
\hline No & $\begin{array}{l}\text { Alternatif } \\
\text { Jawaban }\end{array}$ & $\begin{array}{c}\text { Frekuensi } \\
(\mathrm{F})\end{array}$ & $\begin{array}{c}\text { Persentase } \\
(\%)\end{array}$ \\
\hline a. & Ya & 24 & 64,8 \\
b. & Kadang- & 12 & 32,4 \\
& kadang & & \\
c. & Tidak & 1 & 2,8 \\
\hline & Jumlah & 37 & 100
\end{tabular}

Sumber Data Primer, 2017 (diolah)

Berdasarkan tabel diatas, maka sebagai besar responden dalam penelitian ini menjawab bahwa bahasa anggota penyuluh mudah dipahami sebanyak 24 orang $(64,8 \%)$, dan sebagian kecil menjawab bahwa tidak dapat memahami bahasa anggota penyuluh mudah dipahami sebanyak 1 orang $(2,8 \%)$.

Alasan menjawab bahasa anggota penyuluh mudah dipahami karena dalam penyapaian informasi memiliki kemampuan menguasai materi yang baik sehingga petani dapat mengerti, mudah memahami informasi yang diberikan oleh anggota penyuluh sehingga petani menjadi menarik perhatian dan semangat untuk mengikuti program pertanian demi meningkatkan produksi dan pendapatan pertanian. Sedangkan yang menjawab kadangkadang karena bahasa anggota penyuluhan karena tidak semua anggota penyuluh dapat menyapaikan informasi dengan baik dan yang menjawab tidak karena bahasa anggota penyuluh tidak dapat dipahami oleh petani.

Sehubungan dengan peran pengurus dalam pelaksanaan musyawarah kelompok tani yang menjadi kewajiban dan tanggung jawab setiap penyuluh, mengenalkan adanya tiga (3) tahapan peran penyuluh yang terdiri atas kegiatankegiatan: 
1. Pencairan diri dengan masyarakat penerima manfaat

2. Menggerakan masyarakat untuk melakukan perubahan

3. Pemantapan hubungan dengan masyarakat penerima manfaat

Selaras dengan peran yang harus dimainkan oleh setiap penyuluh maka kualifikasi yang harus dimiliki setiap penyuluh yang mencakup kemampuan berkomunikasi, hal ini tidak hanya terbatas pada kemampuan memilih inovasi dan menggunakan media komunikasi yang efektif, memilih dan menerapkan metode komunikasi pembangunan yang efektif dan efisien, memilih dan menggunakan alat bantu dan peraga yang efektif tetapi yang lebih penting adalah kemampuan dan ketrampilan penyuluh untuk berinteraksi dengan masyarakat penerima manfaatnya.

Sikap penyuluh dapat meenghayati dan bangga terhadap profesinya, serta merasakan bahwa kehadirannya untuk melaksanakan tugas komunikasi pembangunan sangat dibutuhkan masyarakat penerima manfaatnya. Meyakini bahwa inovasi yang disampaikan itu telah teruji kemanfaatannya, memiliki peluang keberhasilan untuk diterapkan pada kondisi alam wilayah kerjanya memberikan keuntungan dan tidak bertentangan dengan nilai-nilai social budaya masyarakat, serta meyakini bahwa inovasi yang akan disampaikan itu benar-benar merupakan kebutuhan nyata meskipun sering kali belum dapat dirasakan masyarakat penerima manfaatnya.
Menyukai dan mencintai masyarakat penerima manfaatnya, dalam artian selalu siap memberikan bantuan atau melaksanakan kegiatan-kegiatan demi berlangsungnya perubahan-perubahan usaha tani maupun perubahan masyarakat penerima manfaatnya.

Karakteristik sosial budaya penyuluh kualifikasi penyuluh tidak cukup hanya dengan memenuhi persyaratan ketrampilan, sikap dan pengetahuan saja, tetapi keadaan latar belakang sosial budaya (bahasa, agama, kebiasaankebiasaan) seringkali lebih banyak menentukan keberhasilan penyuluh yang dilaksanakan. Karena itu, penyuluh yang baik sejauh mungkin harus memiliki latar belakang social budaya yang sesuai dengan keadaan sosial budaya masyarakat penerima manfaatnya.

\section{DAFTAR PUSTAKA}

Suhardiyono., 2002. Penyuluhan, Petunjuk bagi Penyuluh pertanian, Erlangga, Jakarta.

Mardikanto. T. 2003. Penyuluhan Pembangunan Pertanian. Sebelas Maret University Press.

Margono, S., 2009. Membentuk Pola Prilaku Manusia Pembangunan, IPB Press,Bogor.

Dewi, Sunarsih dan Hani. 2009. Sosiologi Komunikasi (Teori, Paradigma, dan Diskursus.Bina Pustaka. Jakarta. 